\title{
GIS Technique in Management of Watershed Developed along the Konkan Coast, Maharashtra, India
}

\author{
Bhavana Umrikar \\ Department of Geology, University of Pune, Pune, India \\ Email: bnumrikar@gmail.com
}

Received 29 April 2015; accepted 9 June 2015; published 12 June 2015

Copyright (C) 2015 by author and Scientific Research Publishing Inc.

This work is licensed under the Creative Commons Attribution International License (CC BY). http://creativecommons.org/licenses/by/4.0/

(c) (i) Open Access

\begin{abstract}
Coastal watersheds differ from inland by their unique features including proximity to the ocean, weather and rainfall patterns, drainage system, subsurface aquifer conditions and geomorphological units. Land use changes and competing needs for water resources are especially more distinctive to such watersheds. This difference leads to put forward the Integrated Coastal Zone Management (ICZM), and is deemed to provide an operational tool for future researchers, developers and policy makers. Some important attributes necessary for watershed management in terms of land capability zonation include drainage, altitude, geology and slopes. The paper incorporates results of representative watershed namely Shringar Tali watershed. GIS technique was used to generate layers like drainage and springs, geology, contour, slopes and Digital Elevation Model (DEM), essential for watershed management. On the basis of interpretation of layers and superimposed picture obtained, Land Capability Zonation Map (LCZM) was prepared. The scope for spring sanctuary development, agro-forestry and aquaculture development is discussed in the paper.
\end{abstract}

\section{Keywords}

Coastal Watershed, Management, GIS, Maharashtra, India

\section{Introduction}

The watershed management programs essentially envisage three main objectives namely to prevent erosion, to enhance water availability and to generate biomass [1] [2]. Watershed management basically requires systematic quantification of the geometry of a watershed where its stream channel system requires measurement of linear 
aspects of the drainage network, area aspects of the drainage basin and relief aspects of channel network and contributing slopes [3]. Such measurements throw light on controls over drainage development, stage of basin development and areas prone to erosion and deposition: the parameters vital for watershed management.

Coastal watershed management is unique and hydrogeologically complex because the rhythm of tides keeps surface- and subsurface hydrogeological conditions changing throughout the day [4] [5]. Besides, declining water levels, soil erosion, deforestation, coastal watersheds also experience problems like seawater intrusion, destruction of mangrove forest, pollution due to aquaculture development etc. [6]. Hence management of coastal watersheds needs more inputs comparing to inland watersheds.

A review of literature reveals that there has been a growing trend of using GIS technique for the watershed management, since it helps in rapid analysis and categorization of land [7]-[9].

This paper, which is a case study from Konkan Coast region in the state of Maharashtra, demonstrates how the GIS technique was utilized in management of the Shringar Tali watershed.

\section{The Area}

The Konkan coastline having approximately $720 \mathrm{~km}$ length is dissected by a number of estuaries and creeks. It includes some significant physiographic features that have a bearing on climate. Based on Landsat imagery, a number of linear features were identified over the Konkan coast [10] [11]. The lineament fabric, as evident from the azimuth frequency diagram of the Konkan coastal plain, is characterized by a strong concentration of lineaments in approximately N-S direction and minor one in E-W direction (Figure 1).

The Konkan region has a typical westward drainage originating from Western Ghats popularly known as Sahyadris. There are number of NNW-SSE flowing tributary streams, $10 \mathrm{~km}$ to $20 \mathrm{~km}$ in length, which empty their water into the westerly flowing rivers. Shringar Tali stream, representative of these streams originates on lateritic plateau and meets E-W flowing Vashishti estuary is the fifth order stream. It is included in the Survey of India toposheet nos. G $47 / 3$ and G $47 / 6$. The area is bounded by latitudes between $17^{\circ} 28^{\prime} \mathrm{N}$ and $17^{\circ} 34^{\prime} \mathrm{N}$ and longitudes between $73^{\circ} 12^{\prime} \mathrm{E}$ and $73^{\circ} 17^{\prime} \mathrm{E}$. Its basin area is $43.32 \mathrm{sq} \mathrm{km}$ and maximum elevation from sea level is 240 $\mathrm{m}$. It is $10.5 \mathrm{~km}$ in length (Figure 2).

\section{Methodology}

Some important attributes necessary for watershed management in terms of Land Capability Zonation include drainage, altitude, geology and slopes. The Survey of India (SOI) toposheets pertaining to the Shringar Tali

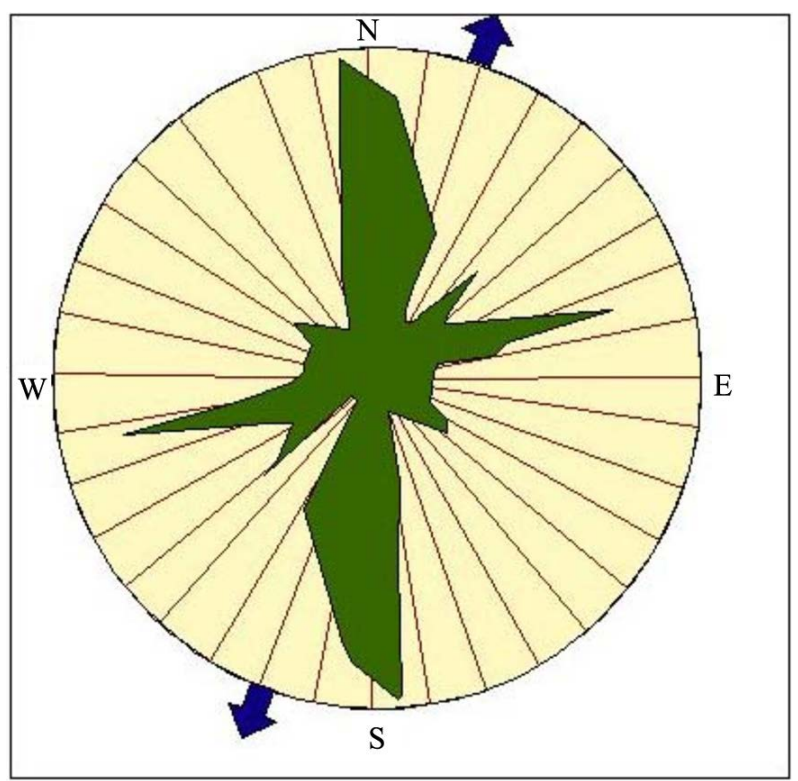

Figure 1. Azimuth frequency diagram for the Konkan coastal plain (after Widdowson and Mitchel) [12]. 


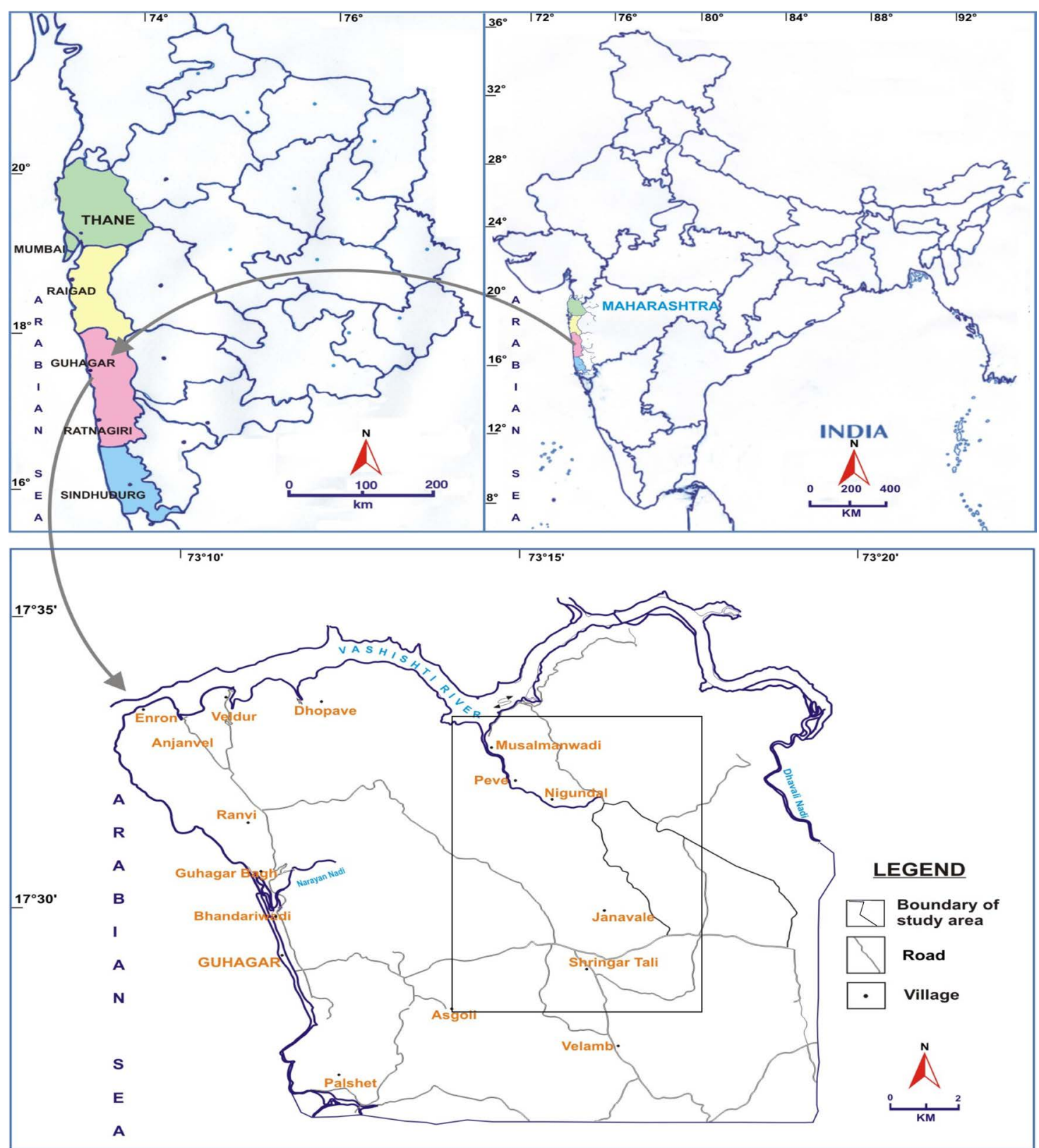

Figure 2. Location map of the study area.

watershed were scanned and digitized for generating the layers of these spatial parameters. The digitized data was utilized for 1) preparing primary layers to cover drainage and spring, contour, geology and 2) deriving secondary layers to generate Digital Elevation Model (Figure 3). This model was in turn used to derive slope and altitude maps. ESRI software suite was used to generate these layers.

Layer I (Streams and Springs): First step in watershed analysis is to draw the drainage divide and mark all the streams present within it. Then follows the ordering of streams: the smallest fingertip streams being designated by order 1 . When two first order streams join, a segment of order 2 is formed; and so forth. The data so obtained is utilized to compute the ratio of number of segments of a given order $(\mathrm{Nu})$ to the number of segments of the next higher order $(\mathrm{Nu}+1)$ called bifurcation ratio using following form

$$
r b=\frac{N u}{n u+1}
$$


It can be seen from Table 1 that the values of bifurcation ratio fall in the range of 3 to 5 for different order streams except for 3rd and 4th order streams. According to Horton [13] the values between 3 and 5 are indicative of erosional control over uniform lithology on drainage development. These values if less than 3 suggest structural control over drainage development. The rectilinear- and parallel- to sub-parallel patterns developed within 3rd and 4th order streams support this inference.

A separate layer of springs was prepared. It was superimposed over a layer of drainage to ascertain relationship between these attributes. The superimposed picture indicates that majority of springs emerge along the streams (Figure 4).

Layer II (Area-Altitude): The area altitude analysis was carried out to obtain the relationship of horizontal

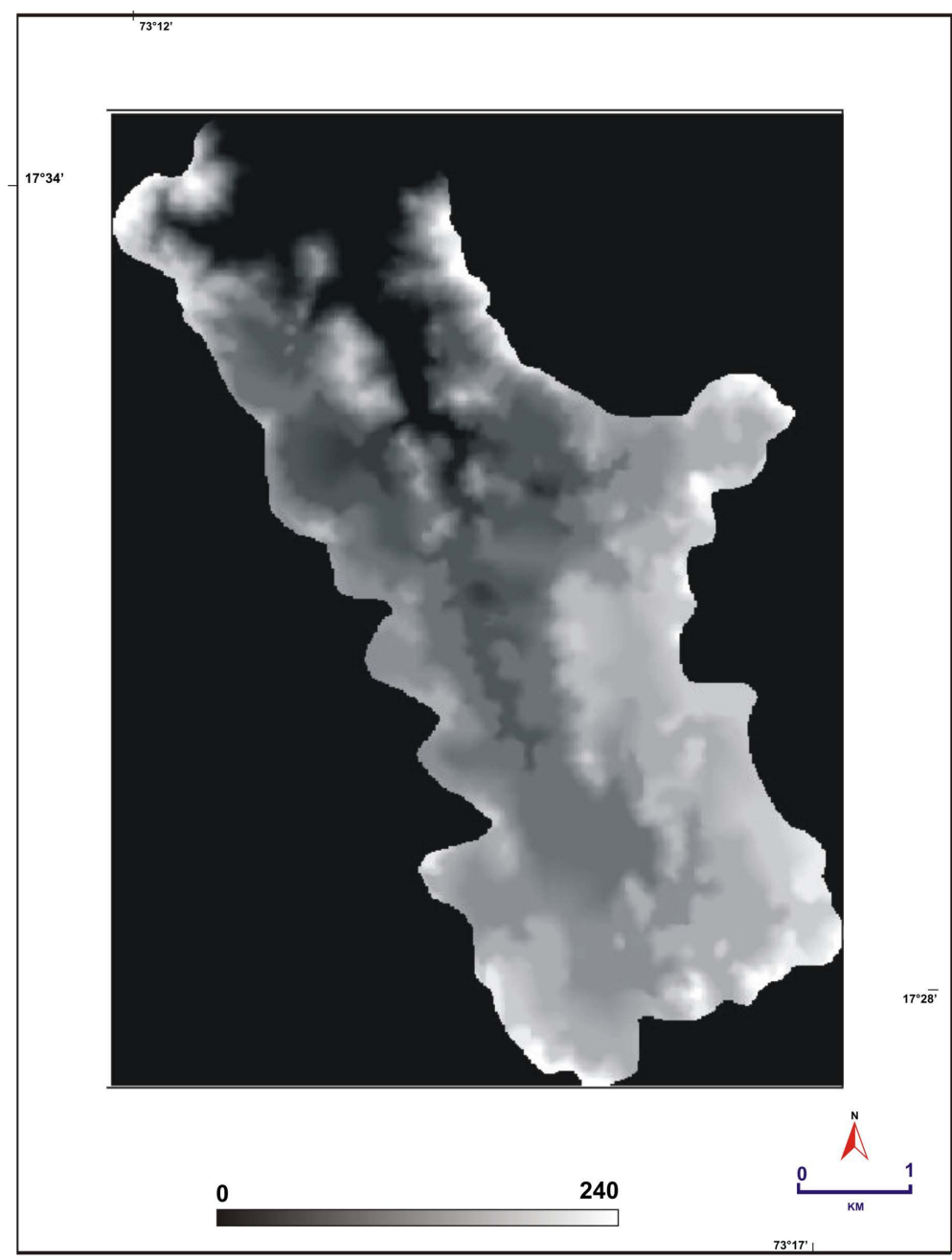

Figure 3. Digital elevation model (dem) of Shringar Tali watershed.

Table 1. Stream data of the Shringar Tali watershed.

\begin{tabular}{cccc}
\hline Stream order & No. of streams & Bifurcation ratio \\
\hline 1 & 159 & 33 & 4.81 \\
2 & 7 & 3.71 \\
3 & 1 & 2.33 \\
4 & 3.00 \\
\hline
\end{tabular}


cross-sectional watershed area to elevation. The layer II representing distribution of contours is shown in Figure 5 and analysis of data is incorporated in Table 2.

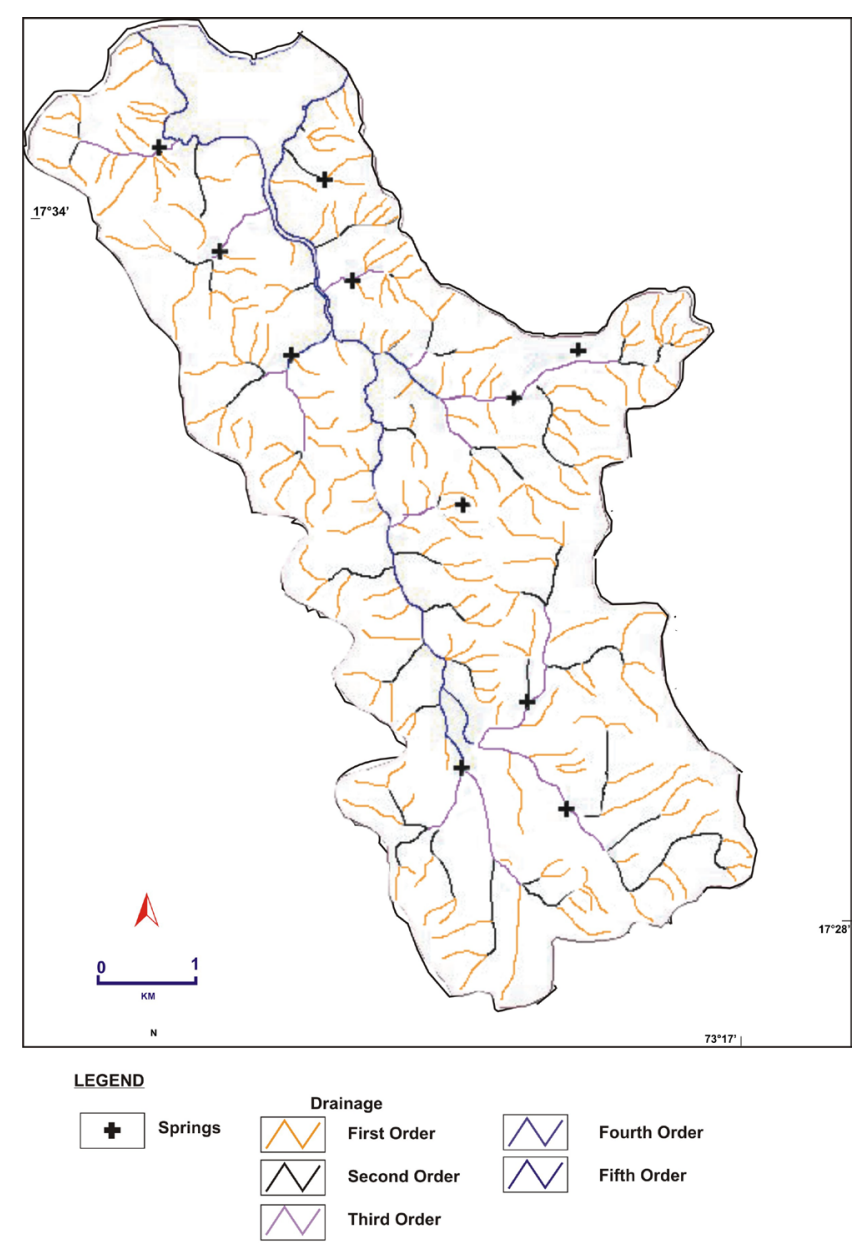

Figure 4. Drainage map showing location of springs.

Table 2. Hypsometric data of the Shringar Tali watershed.

\begin{tabular}{cccccccc}
\hline Contour interval & No. of pixels & Pixel area & Area (sq m) & Area (sq km) & Area \% & Relative area & Relative height \\
\hline 20 & 11,196 & 400 & $4,478,400$ & 4.47 & 10.3588 & 0.100 & 0.083 \\
$21-40$ & 2318 & 400 & 927,200 & 0.92 & 2.14466 & 0.049 & 0.166 \\
$41-60$ & 2904 & 400 & $1,161,600$ & 1.16 & 2.68684 & 0.062 & 0.250 \\
$61-80$ & 10,583 & 400 & $4,233,200$ & 4.23 & 9.79164 & 0.236 & 0.330 \\
$81-100$ & 18,565 & 400 & $7,426,000$ & 7.42 & 17.1767 & 0.396 & 0.416 \\
$101-120$ & 17,021 & 400 & $6,808,400$ & 6.80 & 15.7482 & 0.363 & 0.500 \\
$121-140$ & 21,074 & 400 & $8,429,600$ & 8.42 & 19.4981 & 0.450 & 0.583 \\
$141-160$ & 17,134 & 400 & $6,853,600$ & 6.85 & 15.8527 & 0.366 & 0.660 \\
$161-180$ & 5270 & 400 & $2,108,000$ & 2.10 & 4.87592 & 0.112 & 0.750 \\
$181-200$ & 1505 & 400 & 602,000 & 0.60 & 1.39246 & 0.032 & 0.833 \\
$201-220$ & 417 & 400 & 166,800 & 0.16 & 0.38581 & 0.009 & 0.916 \\
$221-240$ & 95 & 400 & 38,000 & 0.03 & 0.08789 & 0.002 & 1.000 \\
\hline
\end{tabular}




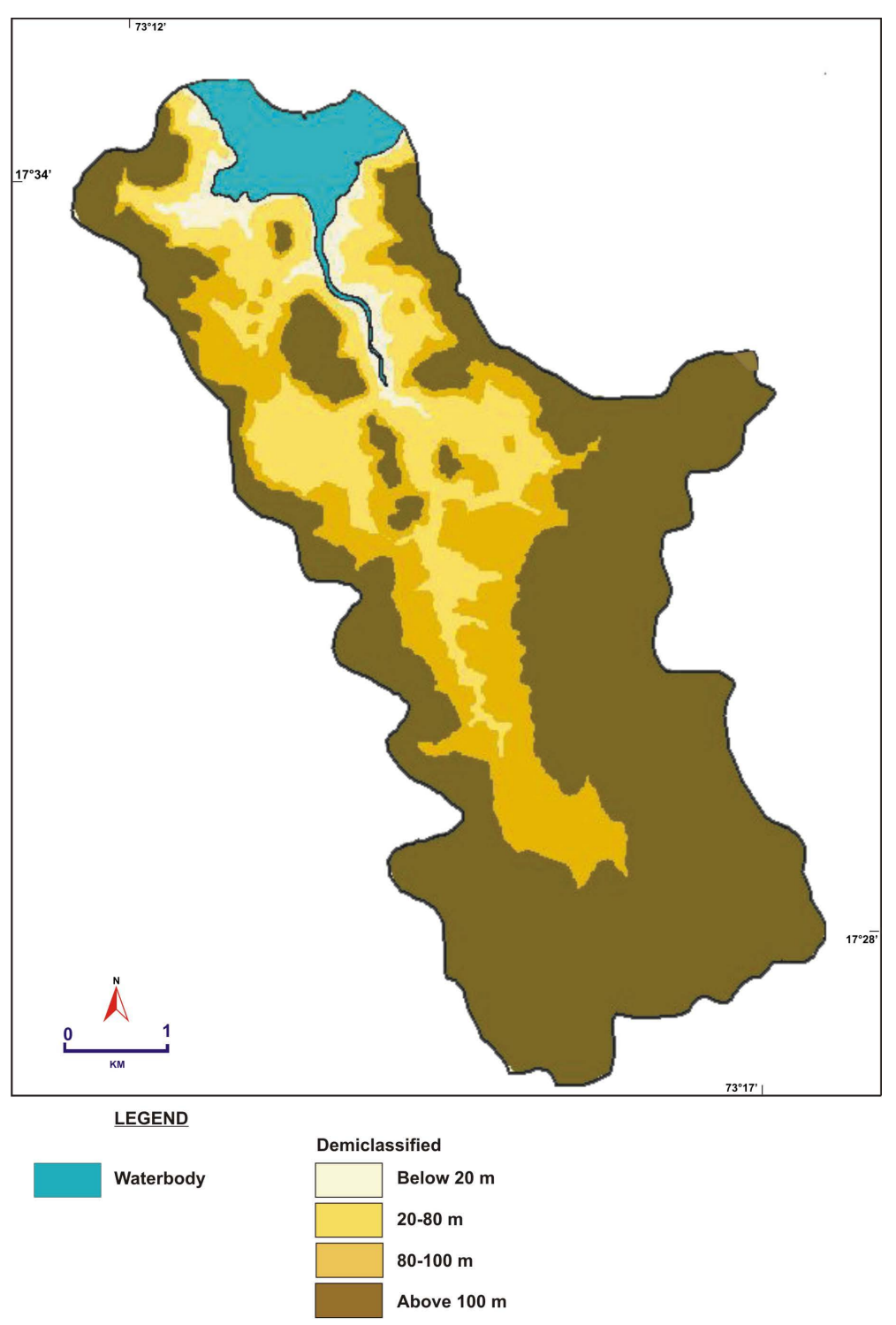

Figure 5. Altitude distribution map.

The hypsometric integral value obtained in the present case is 0.36 . The hypsometric integral values throw light on the stage of development of the Watershed. The values over 0.50, $0.125-0.50$ and below 0.125 are indicative of the youthful-, mature- and monadnock stage of development respectively. The value of 0.36 obtained in the present case thus suggests that the Shringar Tali watershed has reached a mature stage of development.

It is evident from Table 3 that $10.35 \%, 14.62 \%, 17.17 \%$ and $57.84 \%$ of the total area is bounded between $0 \mathrm{~m}$ - $20 \mathrm{~m}, 20 \mathrm{~m}-80 \mathrm{~m}, 80 \mathrm{~m}-100 \mathrm{~m}$ and above $100 \mathrm{~m}$ altitudes respectively.

Layer III (Geology): Three formations viz. the laterite, basalt and sand/mud cover $29.15 \mathrm{sq} \mathrm{km,} 13.37 \mathrm{sq} \mathrm{km}$ and $0.80 \mathrm{sq} \mathrm{km}$ area respectively (Figure 6). The laterites generally occur above $80 \mathrm{~m}$ altitude whereas basalts between $20 \mathrm{~m}$ and $80 \mathrm{~m}$ altitude. The area below $20 \mathrm{~m}$ altitude is occupied by colluvium and sand/mud.

Layer IV (Slopes): Slopes are of utmost importance for rationalization of land-use in watershed because it gives the basis for land capability zonation which in turn assists in land use planning and soil conservation practices. The slopes were grouped into four categories that would suite the land capability criteria [2]. These categories are: 1$)<7^{\circ}$, 2) $7^{\circ}$ to $20^{\circ}$, 3) $20^{\circ}$ to $30^{\circ}$, and 4) $>30^{\circ}$. It is seen from Table 4 that the area covered in $<7^{\circ}$ category is as high as $64.52 \%$. The layer of slope is shown in Figure 7. Most of it is occupied by plateau and only about $4 \%$ below $20 \mathrm{~m}$ contour. $30 \%$ area falls within $7^{\circ}-20^{\circ}$ slope category zone whereas $4.98 \%$ in $20^{\circ}-30^{\circ}$ 


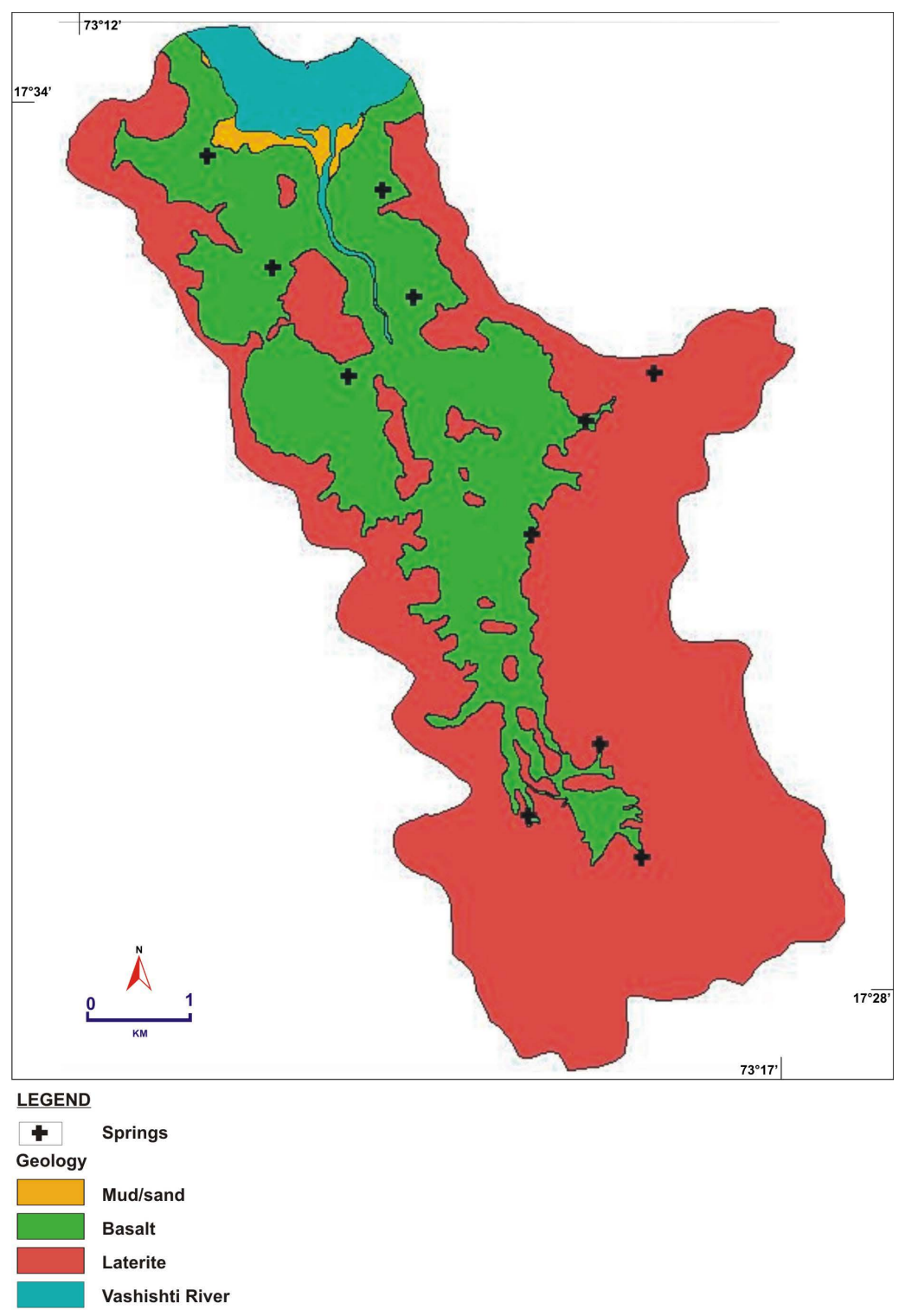

Figure 6. Geological map showing location of springs.

Table 3. Contour-wise distribution of area for land capability zones.

\begin{tabular}{cccccc}
\hline Contour interval & No. Of pixel & Pixel area & Area (sq m) & Area (sq km) & \% area \\
\hline $0-20$ & 11,196 & 400 & $4,478,400$ & 4.4784 & 10.3588 \\
$20-80$ & 15,805 & 400 & $6,322,000$ & 6.3220 & 14.62314 \\
$81-100$ & 18,565 & 400 & $7,426,000$ & 7.4200 & 17.1767 \\
$>100$ & 62,516 & 400 & $25,006,400$ & 25.0064 & 57.84127 \\
\hline
\end{tabular}

slope zone. Only $0.39 \%$ area is occupied by more than $30^{\circ}$ slope.

\section{Model for Watershed Management}

The study area is endowed with rich eco-systems and scenic landforms. The ecosystems, if properly developed and managed, would certainly help minimizing environmental deterioration, promoting tourism, earning foreign exchange, generating jobs thereby preventing migration of population to mega cities like Mumbai and Pune, and 


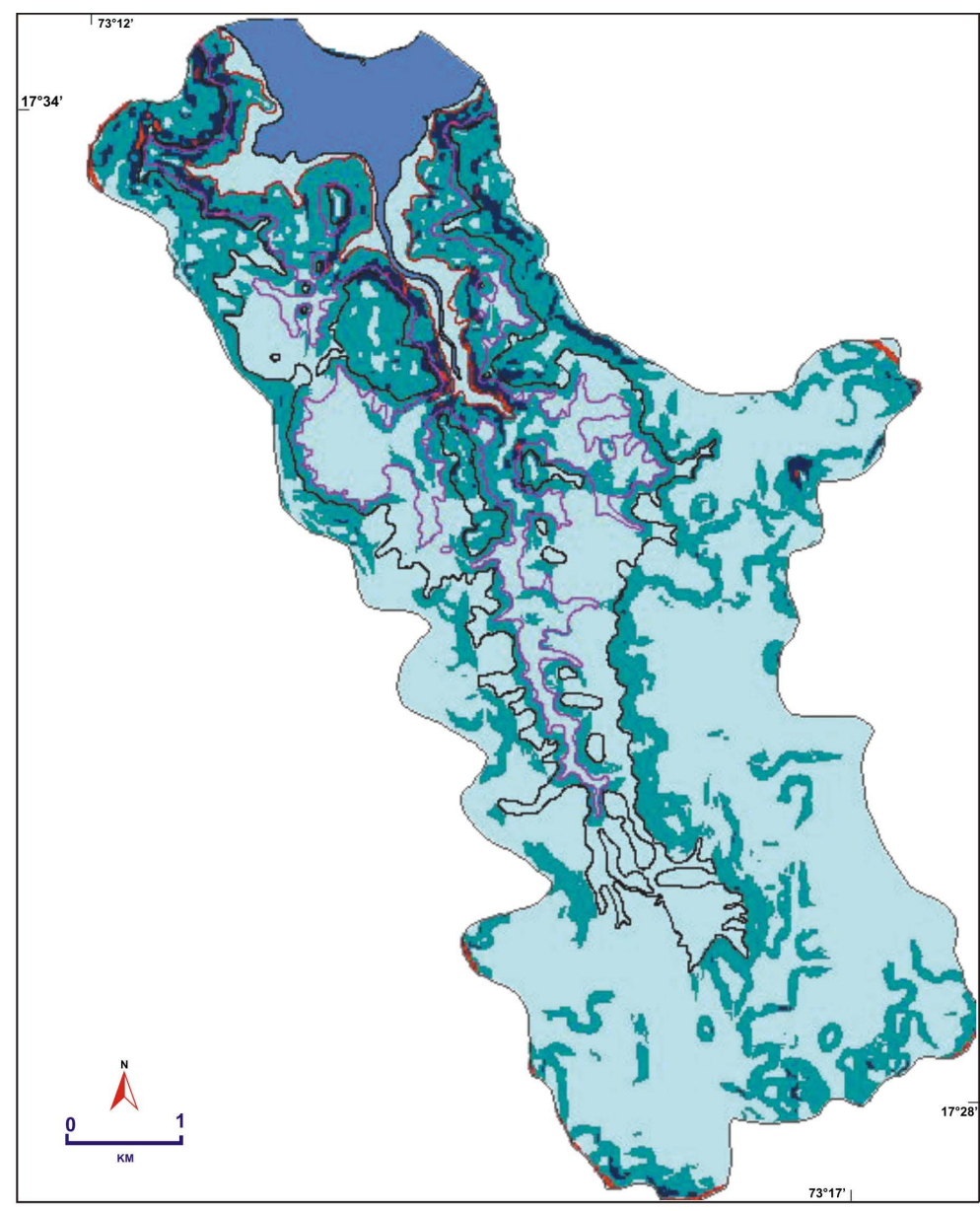

EGEND

\begin{tabular}{|c|c|c|c|c|}
\hline Contou & & Slope & & Zone \\
\hline & $20 \mathrm{~m}$ & & $<7^{\circ}$ & \\
\hline 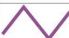 & $80 \mathrm{~m}$ & & $7^{\circ}-20^{\circ}$ & II \\
\hline 1 & $100 \mathrm{~m}$ & & $20^{\circ}-30^{\circ}$ & \\
\hline & Water body & & $>30^{\circ}$ & IV \\
\hline
\end{tabular}

Figure 7. Slope distribution map superimposed with contours.

Table 4. Slope analysis data of the Shringar Tali watershed.

\begin{tabular}{cccccc}
\hline Slope interval & No. Of pixel & Pixel area & $\begin{array}{c}\text { Area } \\
\text { (sq m) }\end{array}$ & $\begin{array}{c}\text { Area } \\
\text { (sq km) }\end{array}$ & \% area \\
\hline$<7^{\circ}$ & 69,644 & 400 & $27,857,600$ & 27.8576 & 64.5282 \\
$7^{\circ}-20^{\circ}$ & 32,494 & 400 & $12,997,600$ & 12.9976 & 30.1071 \\
$20^{\circ}-30^{\circ}$ & 5319 & 400 & $2,148,800$ & 2.1488 & 4.97739 \\
$>30^{\circ}$ & 418 & 400 & 167,200 & 0.1672 & 0.38729 \\
\hline
\end{tabular}

elevating standard of living of local population.

\section{Perspective}

A lot has been said and discussed on anthropogenic changes resulting deterioration of eco-systems. The Guhagar area in general and Shringar Tali watershed in particular is not exception to it. Unfortunately the term eco- 
development, rather than providing meaningful alternatives for conservation, has remained as fashionable slogan in under developed- and developing countries. The issue of eco-development, therefore, needs to be tackled adopting new thinking, conceptualizing holistic and innovative approach that would provide not only the scientific and technological solutions, but also take into account socio-economic needs.

\section{Results and Discussion}

On the basis of interpretation of the layers and superimposed picture obtained, Land Capability Zonation Map (LCZM) was prepared (Figure 8). Table 5 includes summary of zone-wise strategy for watershed management and eco-development including following aspects:

1) Prevention of Soil Erosion and Development of Water Resources,

2) Development of agro-forestry, and

3) Development of Aqua-culture and suggestions for CRZ Act.

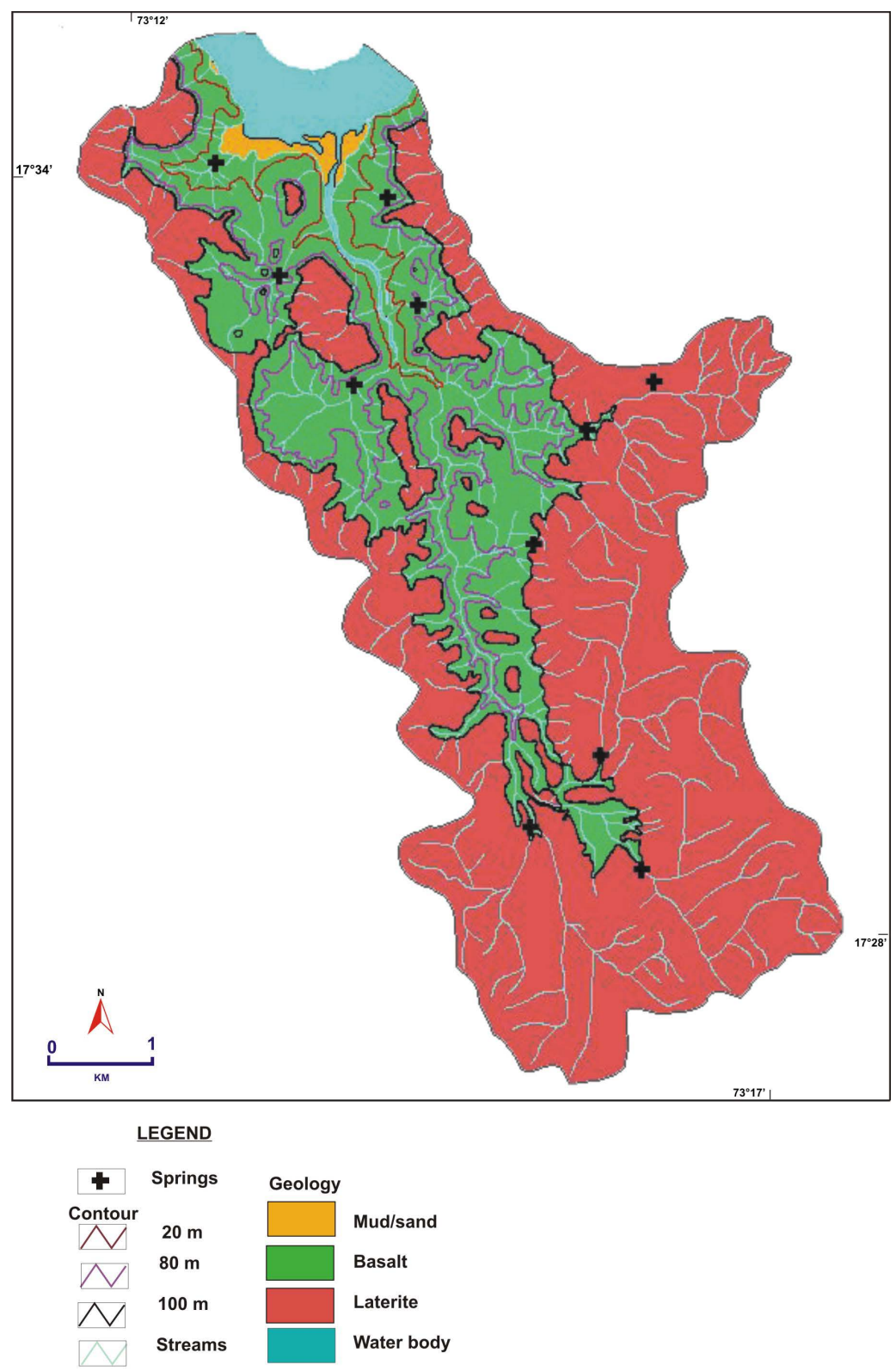

Figure 8. Overlay map of drainage, springs, contour and geology layers. 
Table 5. Details of watershed treatment/eco-development.

\begin{tabular}{|c|c|c|c|}
\hline \multirow{2}{*}{ Zone } & \multicolumn{3}{|c|}{ Watershed treatment/eco-development } \\
\hline & $\begin{array}{l}\text { Prevention of soil erosion/water } \\
\text { harvesting }\end{array}$ & Agro-forestry & Aqua culture/crz \\
\hline I & $\begin{array}{l}\text { Contour bunding, stream bank } \\
\text { treatment, check dams on graded } \\
\text { segment of stream, tidal regulator, } \\
\text { masonry check dams, water } \\
\text { spreading over paddy fields. }\end{array}$ & $\begin{array}{l}\text { Canopy of coconut and beetle nut plantation, } \\
\text { paddy field development, protection of } \\
\text { mangrove forest \& forestation of mangroves } \\
\text { on deforested land wherever possible. }\end{array}$ & $\begin{array}{l}\text { Aqua-culture development above } \\
\text { strand line through small tanks and } \\
\text { ponds, putting tidal regulator along } \\
\text { stream, ban on drilling except for } \\
\text { aqua culture with due precaution. }\end{array}$ \\
\hline II & $\begin{array}{l}\text { Stream bank treatment for 3rd and 4th } \\
\text { order streams, check dams across } \\
\text { graded stretches, plantation to prevent } \\
\text { gully erosion on stream originating in } \\
\text { the zone, terracing \& contour bunding } \\
\text { on spurs. }\end{array}$ & $\begin{array}{l}\text { Paddy cultivation on terraced land, canopy } \\
\text { of orchids of jack fruits, pineapple, amla, } \\
\text { and medicinal plants, grass. }\end{array}$ & $\begin{array}{l}\text { Optimum depth of bore wells only } \\
\text { up to } 20 \text { m datum line. }\end{array}$ \\
\hline III & $\begin{array}{l}\text { Plantation to prevent gully erosion, } \\
\text { terracing on minor spurs, stream } \\
\text { bunds, check dams along graded } \\
\text { stretches of streams. }\end{array}$ & $\begin{array}{l}\text { Canopy of medicinal- and spice plantation, } \\
\text { orchids of mango, cashew, eugenia jambolana. } \\
\text { Allow wild growth of karvanda/grass. }\end{array}$ & $\begin{array}{l}\text { Optimum depth of bore wells only } \\
\text { up to } 20 \text { m datum line. }\end{array}$ \\
\hline IV & $\begin{array}{l}\text { Controlled blasting in the vicinity of } \\
\text { springs, storage of water in } \\
\text { depressions on plateau, check } \\
\text { dams, quarrying. }\end{array}$ & $\begin{array}{l}\text { Mango and cashewnut plantation/grass. } \\
\text { Phreatophytic flora in the vicinity of springs. }\end{array}$ & \\
\hline
\end{tabular}

\subsection{Spring Sanctuary}

The issue of spring sanctuary development requires consideration of two aspects, [14] first is to enhance recharge for increasing the yield and seasonality, and second is to prevent wastage of flowing spring water. The field observations revealed that springs at higher altitude occur along the first or second order streams at the interface of laterite/basalt along the base of minor cliffs. Though discharge of these springs diminishes, they continue to supply water in summer months. The plateau with local depressions, well integrated drainage and incised streams are favourable locales for recharging of surface water into aquifers. One way to increase recharge of such springs is controlled blasting on a grid pattern through drill holes up to $3 \mathrm{~m}$ depth in the basin area of the stream (Figure 9). Another way is to encourage quarrying and divert the surface runoff for storage into abandoned quarry pits which would contribute to the aquifer. This treatment can also be extended in the basin area of the adjoining streams. It may result in converting seepages that occur at more or less same altitudes, into springs [15].

The spring water is stored in the tanks but much of it overflows and contributes to stream flow. It is possible to arrest this stream flow at the confluence of the first order streams by constructing small masonry bunds and larger size structure across second order stream immediately below these bunds (Figure 9). This would prevent wastage and help providing water down slope by gravity.

\subsection{Agro Forestry}

One of the eco-friendly solutions for preventing erosion and generate finance is to undertake plantation program. The naturally occurring vegetation in the study area can be broadly classified into 4 main groups: (A) Littoral or mangrove type, (B) Open scrub type, (C) Moist deciduous type, and (D) Semi evergreen type. Plant communities in the area are not sharply defined as they merge imperceptibly one into another. However, altitude-wise demarcation is seen for some of the species due to marked difference in particle size, composition and $\mathrm{pH}$ of soils as also variation in chemistry of waters. In nutshell, vegetation does not show well-marked lateral characteristic canopies but certainly be differentiable between saline- and fresh water environments.

The Konkan coastal plain in general and study area in particular are rich in medicinal-, spice-, fruit-, foodand fodder plants [16] [17]. Popular mango variety "Alphonso" and the cashew nuts are cultivated on a large scale on plateaus and hill slopes. Coconut and beetle nut cultivation is quite common in the vicinity coastal areas 


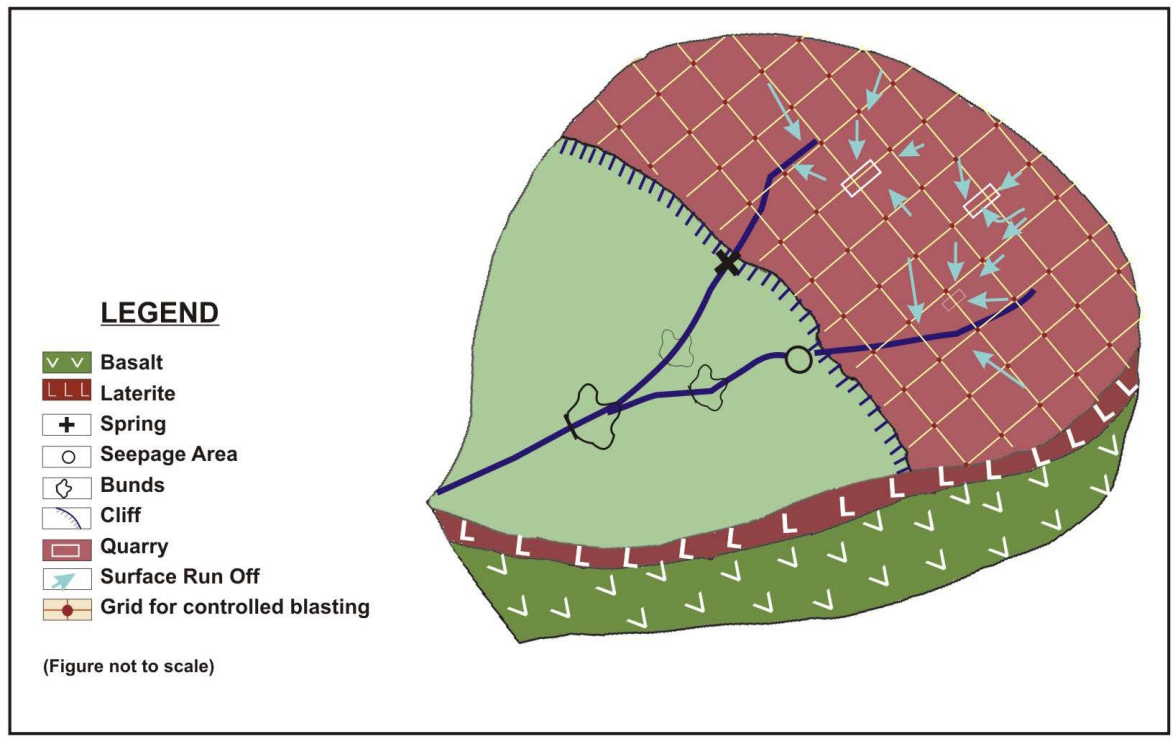

Figure 9. Schematic diagram explaining strategy for spring development.

and almost every village has these groves. Pineapple is another popular fruit cultivated on plains. As for timber, varieties of wood are in demand. With proper management of deciduous or semi-evergreen forests, most of the species can be brought into the approved range for wood based industries. Though Teak does not occur wild, it can be successfully introduced and cultivated as seen from the old teak plantations. Some of the highly palatable fodder grasses are present in the area. The area is quite rich in medicinal plants. There is good scope for introduction and cultivation of several useful species required by pharmaceutical firms.

\subsection{Aqua Culture}

Ecological setting of land adjoining Vashishti river and graded lower stretch of Shringar Tali stream below $20 \mathrm{~m}$ altitude is quite conducive for aqua culture. But these activities pose a problem of environmental degradation by way of deforestation of mangrove forest, pollution and so on. Therefore a few norms can be laid down while undertaking aqua culture development activity. These norms should cover density of aqua-culture tanks, ideal geomorphic setting along the tidal inlet, and cheaper eco-friendly alternative with optimum size of the tank for encouraging local fisherman communities to undertake aquaculture activity.

\subsection{Aqua culture Tanks}

It has been a practice to lift seawater from estuary, creek or tidal inlet during high tide for supply to aqua culture tanks. The water so lifted contains undesirable material such as clay particles, tiny alive fish and other un-decomposed organic material. The filtering of water through costly filtration mechanism is necessary to remove such undesirable material. One way to overcome this problem is to obtain saline water from bore wells. Tectonic setting of the area permits recharging of seawater into deeper aquifers through fractures and joints. Therefore, bore wells drilled below $20 \mathrm{~m}$ altitude are high yielding but release saline water. This situation prompted to suggest that rather than lifting seawater from surface it may be obtained through series of bore wells. A due precaution, however, is necessary to seal the shallow aquifer to prevent leakage of fresh water into deeper aquifer.

The recommended dimension of tanks 0.5 to $1.0 \mathrm{sq}$ ha area [18] is too large, costly and responsible for increasing pollution. Further, it does not encourage local fisherman community to take up such large project because of financial constraints. The small size tanks beyond strand line and lifting of saline water from bore wells can reduce the cost of the project and level of pollution (Figure 10).

The periodic discharge of wastewater from the aqua tanks is the source of pollution since it contains organic feed, excretory matter and dead fish. As has been mentioned earlier mud flats and mangrove forests serve as 


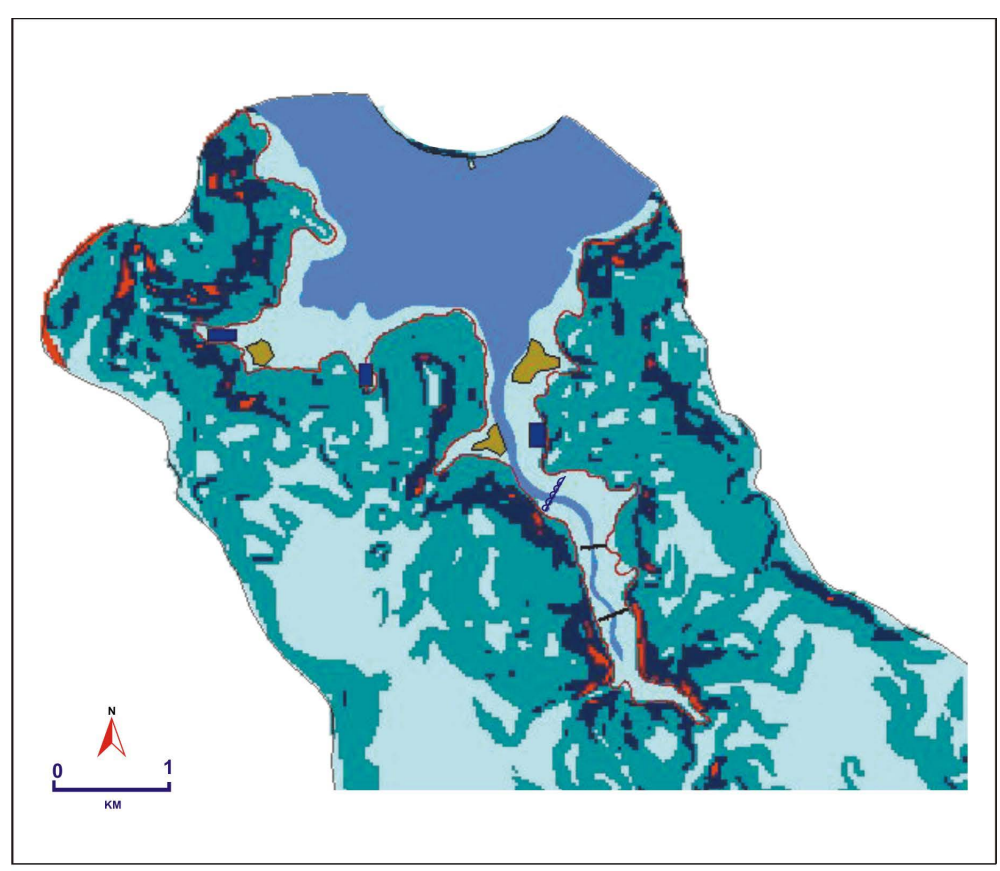

LEGEND

Proposed sites

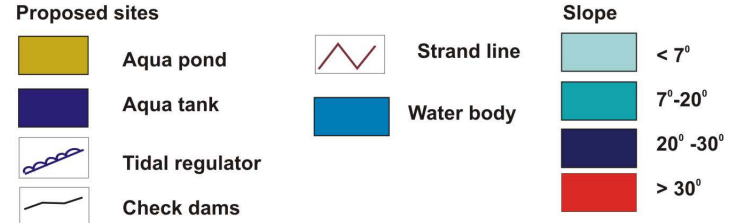

Figure 10. Zoomed view of northen segment of shringar tali watershed. (proposed sites for aqua culture development and watershed management).

breeding ground for fish, crustacean, lamellibranch, gastropod etc. Pollution through aqua-culture activity is a threat to their existence. Research to use organic waste generated through aqua-culture as manure demand consideration.

\subsection{Aqua Culture Ponds}

The beach and mud flat environments are endowed with variety of biogenic structures formed due to feeding, browsing and crawling habits of the crustacean, gastropod, lamellibranch etc. These structures are not only beautiful but also generate curiosity among the visitors, particularly young ones. The places behind mangrove forests provide ideal sites for aqua-ponds to habitat these organisms (Figure 10). Such ponds would certainly add to tourism value in this delicate ecological niche.

\section{Conclusions}

The Shringar Tali watershed, a representative of NNW-SSE running streams originating on lateritic plateau, has been selected to suggest a model for watershed development. The Shringar Tali is a 5th order stream having a basin area of about $43.0 \mathrm{sq} \mathrm{km}$. This basin has reached a mature stage of development as evident from hypsometric data.

On the basis of interpretation of the layers and superimposed picture obtained, treatment oriented Land Capability Zonation Map was prepared (LCZM). On the basis of comparative study of these layers following strategy has been suggested:

1. Zone I: Land with $<7^{\circ}$ slope is prescribed for coconut and, beetle nut canopy, and paddy cultivation; devel- 
opment of aqua culture tanks and ponds; and putting tidal regulator to prevent sea water ingress, and masonry bunds for storage of surface water and preventing downward movement of fresh groundwater. Inputs prescribed for CRZ Act need to be practiced in this zone.

2. Zone II: Land between $7^{\circ}$ to $200^{\circ}$ slope is considered to be treatable with soil conservation measures such as stream bank treatment along graded segments of the streams, check dams, plantation to prevent gully erosion, terracing and contour bunding; and suitable for food-, fruit-, medicinal-, spices- and fodder plantation.

3. Zone III: Land between 200 and 300, is categorized for prescribing soil conservation technique such as check dams and stream bund to prevent gully erosion, terracing on minor spurs etc.; and suitable for fruit-, medicinal-, and fodder plantation, and

4. Zone IV: Land having $>30^{\circ}$ and $<7^{\circ}$ slope on plateau is classified as suitable for soil conservation techniques such as check dams, diverting surface runoff into quarry pits or natural depressions, controlled blasting for development of springs and; orchids of fruit and fodder cultivation.

The extent of laterite plateau in Konkan coastal plain is $4298 \mathrm{sq} \mathrm{km}$. A number of NNW-SSE trending streams have carved their path through this plateau. The Shringar Tali watershed is one of the representatives of these streams. The model suggested for this watershed for management and eco-development, if attempted as a pilot project, could be useful in similar such watersheds with necessary changes.

\section{Acknowledgements}

Author is thankful to Prof. S. S. Thigale for the valuable guidance, help during fieldwork and critically going through the manuscript and to the Head, Department of Geology, University of Pune for extending the facilities.

\section{References}

[1] Indian National Committee for IHP (1981) Watershed Management in India. HYDCOM Report, CSIR Publ., New Delhi, 56p.

[2] Singh, R.V. (2000) Watershed Planning and Management. Yash Publishing House, Bikaner, 459p.

[3] Umrikar, B.N., Dhanve, S.S., Dagde, G.R. and Gawai, R.O. (2013) Quantitative Geomorphological Analysis for Characterization of Selected Watersheds in Western Maharashtra, India. International Journal of Remote Sensing \& Geosciences (IJRSG), 2, 8-15.

[4] Jadhav, F.J., Umrikar, B.N. and Thigale, S.S. (2001) Impact of Coastal Processes on the Watersheds along Coast of Western Maharashtra. In: Seminar Vol. An Integrated Approach for Strengthening and Protecting Drinking Water Sources, G.S.D.A., Pune, 17-24.

[5] Thigale, S.S., Duraiswami, R.A. and Umrikar, B.N. (2006) Some Hydrogeological Aspects of the Shallow Beach Rock (Calc-Arenite) Aquifers along Maharashtra Coast, India. In: Xu, Y.J. and Singh, V.P., Eds., Coastal Environment and Water Quality International conference Book, Section 2: Saltwater Intrusion, Water Resources Publ., LLC., Baton Rouge, 9.

[6] Umrikar, B.N. and Thigale, S.S. (2007) Sea Water Ingress Study along the Guhagar Coast of Maharashtra with Reference to the Harmonious Water Resource Development. Journal of the Geological Society of India, 69, 933-942.

[7] Maggirwar, B.C. and Umrikar, B.N. (2009) Possibility of Artificial Recharge in Overdeveloped Miniwatersheds: RS-GIS Approach. e-Journal, Earth Science India, 2, 101-110. http://www.earthscienceindia.info

[8] Malczewski, J. (2003) GIS-Multicriteria Evaluation with Ordered Weighted Averaging (OWA): Case Study of Developing Watershed Management Strategies. Environmental and Planning, 35, 1769-1784. http://dx.doi.org/10.1068/a35156

[9] Shaban, A. (2005) Watershed Characteristics, Land Use and Fabric: The Application of Remote Sensing and Geographic Information Systems. Lakes and Reservoirs: Research and Management, 10, 85-92. http://dx.doi.org/10.1111/j.1440-1770.2005.00264.x

[10] Powar, K.B. (1981) Lineament Fabric and Dyke Pattern in the Western Part of the Deccan Volcanic Province. Proceedings of the Group Discussion, Deccan Volcanic and Related Basalt Provinces in Other Parts of the World, Memoir Geological Society of India, v. 36, 45-57.

[11] Qureshy, M.N. (1982) Gravity Anomalies, Isostasy and Crust Mantle Relations in the Deccan Trap and Contiguous Regions, India. In: Subbarao, K.V. and Sukheswala, R.N., Eds., Deccan Volcanism and Related Basalt Provinces in other Parts of the World, Memoir Geological Society of India, v. 3, 184-197.

[12] Widdowson, M. and Mitchell, C. (1999) Large-Scale Stratigraphical, Structural and Geomorphological Constraints on Earthquakes in the Southern Deccan Traps, India. The Case for Denudationally Driven Seismicity. Memoir Geological 
Society of India, 43, 425-452.

[13] Horton, R.E. (1945) Erosional Development of Streams and Drainage Basins, Hydrogeological Approach to Qualitative Morphology. Geological Society of America Bulletin, 26, 275-370. http://dx.doi.org/10.1130/0016-7606(1945)56[275:EDOSAT]2.0.CO;2

[14] Basak, P.G. and Prabha Sanker, P.N. (1984) Development of Springs in the Western Ghats. In: (Nair, K.S.S.; Gnanaharan, R. and Kedharnath, S., Eds., Ecodevelopment of Western Ghats, Kerala Forest Research Inst. publ., Peechi, $178-180$.

[15] Umrikar, B.N. (2004) Development of Spring Sanctuary: Case Study of Guhagar Area, District Ratnagiri, Maharashtra. Journal of Gondwana Geological Society India, 19, 183-189.

[16] Cooke, T. (1901-1908) The Flora of the Presidency of Bombay. Taylor and Francis, London, 672 p.

[17] Kulkarni, B.G. (1988) Flora of Sindhudurg. Bot. Surv. Ind. publ., Calcutta, 605 p.

[18] Central Institute of Fisheries Education (1994) Management of Giant Freshwater Prawn Hatchery. CIFE publ., Indian Council of Agricultural Research, Mumbai, 138 p. 